\title{
Sustainable city logistics - Making cargo cycles viable for urban freight transport
}

DOI:

10.1016/j.rtbm.2015.02.001

\section{Document Version}

Accepted author manuscript

Link to publication record in Manchester Research Explorer

\section{Citation for published version (APA):}

Schliwa, G., Armitage, R., Aziz, S., Evans, J., \& Rhoades, J. (2015). Sustainable city logistics - Making cargo cycles viable for urban freight transport. Research in Transportation Business and Management, 15, 50-57. https://doi.org/10.1016/j.rtbm.2015.02.001

\section{Published in:}

Research in Transportation Business and Management

\section{Citing this paper}

Please note that where the full-text provided on Manchester Research Explorer is the Author Accepted Manuscript or Proof version this may differ from the final Published version. If citing, it is advised that you check and use the publisher's definitive version.

\section{General rights}

Copyright and moral rights for the publications made accessible in the Research Explorer are retained by the authors and/or other copyright owners and it is a condition of accessing publications that users recognise and abide by the legal requirements associated with these rights.

\section{Takedown policy}

If you believe that this document breaches copyright please refer to the University of Manchester's Takedown Procedures [http://man.ac.uk/04Y6Bo] or contact uml.scholarlycommunications@manchester.ac.uk providing relevant details, so we can investigate your claim.

\section{OPEN ACCESS}




\section{Sustainable city logistics - Making cargo cycles viable for urban freight transport}

Article in Research in Transportation Business and Management · March 2015

DOI: $10.1016 / j . r t b m .2015 .02 .001$

CITATIONS

5 authors, including:

\section{Gabriele Schliwa}

The University of Manchester

9 PUBLICATIONS 9 CITATIONS

SEE PROFILE

James Evans

The University of Manchester

49 PUBLICATIONS 843 CITATIONS

SEE PROFILE

\section{Sara Aziz}

The University of Manchester

1 PUBLICATION 3 CITATIONS

SEE PROFILE

Jasmine Rhoades

The University of Manchester

1 PUBLICATION 3 CITATIONS

SEE PROFILE 


\title{
Sustainable city logistics - Making cargo cycles viable for urban freight transport
}

\author{
Gabriele Schliwa a, ${ }^{\text {a }}$, Richard Armitage ${ }^{\mathrm{b}}$, Sara Aziz a , James Evans ${ }^{a}$, Jasmine Rhoades ${ }^{\text {a }}$ \\ a School of Environment, Education and Development (SEED), The University of Manchester, Room 1.32, Humanities Bridgeford Street, Oxford Road, Manchester M13 9PL, United Kingdom \\ ${ }^{\mathrm{b}}$ European Cycle Logistics Federation, United Kingdom
}

\section{A R T I C L E I N F O}

\section{Article history:}

Received 20 October 2014

Received in revised form 16 February 2015

Accepted 18 February 2015

Available online $\mathrm{xxxx}$

\section{Keywords:}

Urban freight transport

Sustainable city logistics

Cargo bikes

Urban governance

\begin{abstract}
A B S T R A C T
Urban freight and city logistics are central to the UK economy, but face a number of economic and environmental challenges. This paper contributes to a new body of research that investigates the potential of cargo cycles to make city logistics more sustainable and explores ways to encourage their diffusion. The paper makes three key contributions. First, it develops a typology of cycle logistics based on a literature review and expert interviews in order to clarify definitions and terminology. Second, it identifies perception issues, lack of awareness and regulations as major barriers to wider implementation at city level based on snap-shot case studies. Third, it suggests a sustainable city logistics framework for urban governance, logistic operations and future research, to harness the potential of using cargo cycles for sustainable urban freight transport. The paper argues that local authorities have a key role to play in creating conditions that incentivise large logistic companies such as DHL, Hermes and TNT to integrate cargo cycles into their supply chain and hence drive a long-term modal shift. The findings of the paper are of interest to policy makers, urban logistic operators, research institutions and citizens as potential customers.
\end{abstract}

(c) 2015 Elsevier Ltd. All rights reserved.

\section{Introduction}

Cities need to identify new strategies to increase quality of life of their citizens while maintaining economic competitiveness. Over 50\% of the world's population is now living in cities (Grimm et al., 2008). In Europe, around $75 \%$ of the population already lives in urban areas (European Commission, 2014). Without fundamental system changes, the trend towards urbanised living is leading to ever increasing congestion and pollution levels and a number of further challenges caused by high population density. Despite increasing challenges caused by urbanisation and densification, citizens demand liveable city centres. Therefore cities need to ensure quality of life for their citizen while maintaining access to goods and services. In this context, urban mobility plays a key role in the promotion of sustainable urban development of a city. In particular, an efficient freight transport system is required as it plays a significant role in the competitiveness of an urban area and represents an important element for the local economy regarding the employment and income that it generates (Russo \& Comi, 2010).

Urban mobility accounts for $40 \%$ of all $\mathrm{CO}_{2}$ emissions of road transport and up to $70 \%$ of other pollutants from transport (European Commission, 2015). Urban congestion is not only causing the increase in environmental pollution and energy consumption, but also increases

\footnotetext{
* Corresponding author. Tel.: + 447472742047

E-mail addresses: gabriele.schliwa@manchester.ac.uk (G. Schliwa), ratc@me.com (R. Armitage), sara.aziz@hotmail.co.uk (S. Aziz),James.Z.Evans@manchester.ac.uk (J. Evans), jazzrhoades@hotmail.co.uk (J. Rhoades).
}

the length of private and commercial journeys. Every year the European economy loses approximately $1 \%$ of Gross Domestic Product (GDP) due to congestion (European Commission, 2011). These facts directly relate to public health as traffic emissions are responsible for $70 \%$ of the cancerous and other dangerous substances (Silva \& Ribero, 2009). As confirmed by several empirical studies urban freight vehicles account for $6-18 \%$ of total urban travel (Cambridge Semantics, 2004; Figliozzi, 2010 ), for $19 \%$ of energy use and $21 \%$ of $\mathrm{CO}_{2}$ emissions (Russo \& Comi, 2012; Schoemaker, Allen, Huschebek, \& Monigl, 2006). Although urban freight and logistics are central to the UK economy, the sector faces several emerging economic and environmental challenges fuelled by the mega trend of rapidly growing e-commerce and rising number of diesel vans to meet demand (CILT, 2011). Sustainable city logistics solutions are required to address these problems in the city centres (Russo \& Comi, 2012).

Cargo cycles are a zero emission alternative to light goods vehicles in city centres. This paper improves our understanding of how to develop cycle logistics to reduce the adverse impacts of urban goods deliveries without reducing the quality of city living. It identifies reasons why cargo cycles have to date remained a niche solution and how they might become a viable mainstream activity in the UK, drawing implications for cities in Europe.

This paper is structured as follows. Chapter 2 provides an overview on literature engaging with cycle logistics and presents key findings, leading to Chapter 3, which defines the research questions, data collection and methods. Chapter 4 sets out a typology of cycle logistics within a sustainable city logistics framework, followed by an analysis of three 
distinct UK case studies in Chapter 5. Chapter 6 discusses research and policy implications emerging from the previous sections and draws conclusions.

\section{Cargo cycles as vehicles for sustainable city logistics}

To date, there is a lack of structured research into the use of cargo cycles within city logistics (De Decker, 2012; Gruber, Kihm, \& Lenz, 2014; Lenz \& Riehle, 2013). This chapter presents the findings from a systematic literature review that summarises existing research and identifies the potential of cargo bikes in sustainable urban logistics. For academic papers and reports, searches within academic databases Science Direct (www.sciencedirect.com) and Web of Science (webofknowledge.com) were performed to find relevant literature within the field of sustainable urban freight transport addressing the use of bicycles, cargo bikes, cargo trikes and electrically assisted pedal cycles (Rowley \& Slack, 2004).

As Table 2-1 shows, studies are mostly limited to the European context, and focus on identifying the market potential across the logistics sector or on specific case studies of either cities or companies. While cycle freight is being used today in many major cities, popular examples are based in Europe including in Paris, London and Brussels (Conway, Fatisson, Eickemeyer, Cheng, \& Peters, 2011; Janjevic \& Ndiaye, 2014). Existing studies range from making a clear distinction between cargo cycles and electrically assisted cargo cycles ("electric cargo bikes (E-CB)", "small electric vehicles (SEV)") or referring to both. Overall, studies find that the use of cargo cycles represent a viable solution for urban freight transport.

For example, Lenz and Riehle (2013) suggest that cycle freight can form around $25 \%$ of city centre commercial traffic in the medium term and that a potential market does exist. The recent outcome of the European project Cyclelogistics indicates an even higher potential stating that in average $51 \%$ of all motorised trips in European cities that involve transport of goods could be shifted to bikes or cargo bikes. In their quantitative analysis of operational and external costs Melo, Baptista, and Costa (2014) suggest that SEVs are a viable solution to satisfy both public and private stakeholders. An important operational

Table 2-1

Overview of key references and projects on the use of cargo cycles in sustainable city logistics.

\begin{tabular}{|c|c|c|c|c|}
\hline Research subject & Authors & Content & Scope & Key findings \\
\hline Small electric vehicles (SEV) & Melo et al. (2014) & Quantitative analysis & Portugal & $\begin{array}{l}\text { SEVs are a viable solution to satisfy public and private } \\
\text { stakeholders, when operational and external costs are } \\
\text { fully accounted. }\end{array}$ \\
\hline Electric cargo bikes (E-CB) & $\begin{array}{l}\text { Gruber, Ehrler, and Lenz } \\
\text { (2013); Gruber et al. } \\
\text { (2014) }\end{array}$ & $\begin{array}{l}\text { Technical potential, user } \\
\text { requirements }\end{array}$ & Berlin, Germany & $\begin{array}{l}19 \%-48 \% \text { of the mileage of courier logistics done by } \\
\text { combustion engine vehicles could be substituted by } \\
\text { electric cargo bikes. }\end{array}$ \\
\hline Bikes for urban freight & $\begin{array}{l}\text { Lenz and Riehle (2013); } \\
\text { Riehle (2012) }\end{array}$ & Exploratory study & Europe & $\begin{array}{l}\text { High potential for the food and courier, express \& parcel } \\
\text { (CEP) market. Obstacle: perception of cargo cycles as a } \\
\text { suitable mode of transport and their acceptance with } \\
\text { (potential) customers. }\end{array}$ \\
\hline $\begin{array}{l}\text { Freight tricycles for urban } \\
\text { micro-consolidation } \\
\text { (UMC) and last mile }\end{array}$ & Conway et al. (2011) & $\begin{array}{l}\text { Comparative analysis of Paris, } \\
\text { London, and NYC operations to } \\
\text { identify potential for Manhattan }\end{array}$ & $\begin{array}{l}\text { London, UK } \\
\text { Paris, France } \\
\text { New York, US }\end{array}$ & $\begin{array}{l}\text { Freight can be shifted to tricycles without increasing } \\
\text { overall costs and at the same time reducing social } \\
\text { externalities. Public financial support for UMCs serving } \\
\text { single- or multiple-carrier operations could be justified } \\
\text { by traffic and environmental improvements and job } \\
\text { creation. }\end{array}$ \\
\hline $\begin{array}{l}\text { Bicycle messengers } \\
\text { Bike couriers }\end{array}$ & $\begin{array}{l}\text { Maes and Vanelslander } \\
(2012)\end{array}$ & Exploratory study & $\begin{array}{l}\text { Belgium, } \\
\text { Netherlands }\end{array}$ & $\begin{array}{l}\text { Specific market for bike couriers exists. Obstacles: } \\
\text { "chicken-egg-problem", doubts about } \\
\text { professionalisation and linkages with logistical network. }\end{array}$ \\
\hline $\begin{array}{l}\text { Trends and innovation in } \\
\text { city logistics }\end{array}$ & $\begin{array}{l}\text { Taniguchi, Thompson, and } \\
\text { Yamada (2014); Balm, } \\
\text { Browne, Leonardi, and } \\
\text { Quak (2014) }\end{array}$ & $\begin{array}{l}\text { Trends and developing of evaluation } \\
\text { framework to support diffusion of } \\
\text { innovation }\end{array}$ & Diverse & $\begin{array}{l}\text { Electrically assisted tricycles along with small electric } \\
\text { vehicles acknowledged as trend and innovation in city } \\
\text { logistics, e.g. case study in Brussels; evaluation } \\
\text { frameworks needed and being developed for cross-city } \\
\text { learning }\end{array}$ \\
\hline $\begin{array}{l}\text { City logistics, sustainable } \\
\text { city logistics }\end{array}$ & $\begin{array}{l}\text { Russo and Comi (2010, } \\
\text { 2012);Taniguchi } \\
\text { (2014);Taniguchi et al. } \\
\text { (2014) }\end{array}$ & $\begin{array}{l}\text { Concepts and measures for city } \\
\text { logistics in sustainable and liveable } \\
\text { cities }\end{array}$ & $\begin{array}{l}\text { Europe, } \\
\text { worldwide }\end{array}$ & $\begin{array}{l}\text { Three elements are essential for promoting city logistics; } \\
\text { (a) application of innovative ICT (b) change in mind-sets } \\
\text { of logistics managers, and (c) public-private } \\
\text { partnerships; from public utility point of view, the most } \\
\text { important aspect is to promote a sustainable } \\
\text { development strategy }\end{array}$ \\
\hline $\begin{array}{l}\text { Role of urban consolidation } \\
\text { centres in use with } \\
\text { electric vehicles and } \\
\text { electric cargo cycles }\end{array}$ & Browne et al. (2011) & $\begin{array}{l}\text { In depth case study of Gnewt Cargo, } \\
\text { London }\end{array}$ & London, UK & $\begin{array}{l}\text { Total distance travelled and the } \mathrm{CO}_{2} \mathrm{e} \text { emissions per } \\
\text { parcel delivered fell by } 14 \% \text { and } 55 \% \text { as a result of this } \\
\text { delivery system; trial successful from company's } \\
\text { perspective in transport, environmental and financial } \\
\text { terms and therefore decided to continue the operation. }\end{array}$ \\
\hline $\begin{array}{l}\text { "Ich ersetze ein auto" } \\
\text { (i.e. "I substitute a car") }\end{array}$ & $\begin{array}{l}\text { Institute of Transport } \\
\text { Research at DLR }\end{array}$ & $\begin{array}{l}\text { National Climate Initiative project } \\
\text { funded by the German Federal } \\
\text { Ministry for the Environment April } \\
\text { 2012-June } 2014\end{array}$ & $\begin{array}{l}\text { Germany } \\
\text { (8 cities) }\end{array}$ & $\begin{array}{l}\text { E-CB is more accepted by bike messengers than car users; } \\
\text { transition towards use of electric cargo bikes for the“last } \\
\text { mile" of urban deliveries is not yet complete. } \\
\text { www.ich-ersetze-ein-auto.de }\end{array}$ \\
\hline "Cyclelogistics" & $\begin{array}{l}\text { FGM, AMOR, Outspoken, } \\
\text { ECF, CTC }\end{array}$ & $\begin{array}{l}\text { EU project co-funded by Intelligent } \\
\text { Energy Europe Programme } \\
\text { 2011-2014 }\end{array}$ & Europe & $\begin{array}{l}\text { In average } 51 \% \text { of all motorised trips in European cities } \\
\text { that involve transport of goods could be shifted to bikes } \\
\text { or cargo bikes. } \\
\text { http://cyclelogistics.eu }\end{array}$ \\
\hline "Pro E-bike" & $\begin{array}{l}\text { Energy Institute Hrvoje } \\
\text { Požar (project } \\
\text { coordinator) }\end{array}$ & $\begin{array}{l}\text { EU project co-funded by Intelligent } \\
\text { Energy Europe April } 2013 \text { - March } \\
2016\end{array}$ & $\begin{array}{l}\text { Currently } 30 \\
\text { pilot companies } \\
\text { in } 8 \text { European } \\
\text { pilot cities }\end{array}$ & $\begin{array}{l}\text { Programme, promoting "E - bikes", for delivery of goods } \\
\text { and passenger transport, individual information and } \\
\text { findings available via } \\
\text { www.pro-e-bike.org }\end{array}$ \\
\hline "Cyclelogistics Ahead" & Cycle logistics Federation & $\begin{array}{l}\text { EU project co-funded by Intelligent } \\
\text { Energy Europe Programme May } \\
\text { 2014-April } 2017\end{array}$ & Europe & $\begin{array}{l}\text { Cyclelogistics Ahead builds on the Cyclelogistics project. } \\
\text { The main aim is to reduce energy consumption and } \\
\text { emissions from freight transport in urban areas by } \\
\text { triggering near zero emission logistics applications across } \\
\text { Europe. }\end{array}$ \\
\hline
\end{tabular}


consideration here is that E-CBs are positioned between bikes and cars in terms of cost, payload and range, which makes them well suited to specific logistical challenges (Lenz \& Riehle, 2013). Specific areas of application and markets include courier, express and parcel (CEP) services and the delivery of basic products in catering, but there is a significant potential for cycle freight to carry out deliveries with small volumes and comparatively low weight (ibid). In terms of decarbonising the urban logistics sector, a London based case study finds that the total distance travelled and the $\mathrm{CO}_{2} \mathrm{e}$ emissions per parcel delivered fell by $20 \%$ and $55 \%$ respectively as a result of a delivery system utilising urban consolidation centres and small electric vehicles and cargo tricycles (Allen, Browne, Woodburn, \& Leonardi, 2012), while a Dutch study estimated possible annual fuel savings for the Netherlands of $8,500,0001$ of diesel, or 21,000 tonnes of $\mathrm{CO}_{2}$ (Maes \& Vanelslander, 2012). E-CBs have the greatest potential in urban areas due to their ability to work around congestion and access areas with environmental or delivery period restrictions (Lenz \& Riehle, 2013).

In the past, most cycle logistics businesses operated on a small scale and were rarely linked either vertically or horizontally with other logistics companies. Existing research suggests that companies do not feel that bike couriers are sufficiently connected to the global network but are relatively local or at best regional to offer the kind of same-day delivery services that underpin much e-commerce (Maes \& Vanelslander, 2012). This seems to be an oversight given almost weekly reports about the deployment of relatively costly and untried technologies like drones to facilitate urban delivery (Rawn, 2015). However, more recently large logistic companies increasingly consider cycle logistic solutions and local SME's throughout the UK have started to work with DHL and the like which indicates a shift within the industry (Armstrong, 2015; Barner, 2014).

Existing studies also identify a number of essential preconditions for the growth of cargo bike logistics. They require space for central depots, referred to as Urban Consolidation Centre (UCC) (Allen et al., 2012; Browne, Allen, \& Leonardi, 2011, 2011), Urban Distribution Centre (UDC) (Russo \& Comi, 2010) or Urban Micro-Consolidation Centre (UMC) (Conway et al., 2011) preferably on the edge of the city centre. Further, local policies are also identified as key enablers. Any planning decisions that increase the direct or indirect costs of driving and parking cars and vans in cities act to encourage the adoption of cargo cycles as mode of transport (Gruber et al., 2014; Reiter, 2013; Russo \& Comi, 2012). Perhaps unsurprisingly a key enabling factor would be the greater recognition of these factors and the specific needs of cargo cycles, like for example dropped kerbs, amongst urban planners.

Beyond this though, still the largest obstacle to the broader uptake of cargo cycles is identified as being the general lack of recognition amongst users and customers that they represent a suitable mode of transport (Gruber et al., 2014; Lenz \& Riehle, 2013; Reiter, 2013; Riehle, 2012). Despite several recent case studies concluding that the shift from motorised to bike-based delivery is a viable option for urban freight transportation (Lenz \& Riehle, 2013; Maes \& Vanelslander, 2012), the commercial uptake of cycle logistics businesses and the use of bikes to deliver urban freight have not yet found their way into mainstream yet. With regards to small electric vehicles including electrically assist tricycles, Melo et al. (2014) find that benefits exist, but "they are not significant enough to drive suppliers for their adoption". As Lenz and Riehle (2013) point out, different modes of courier services compete in very similar markets with the result that a number of niche services can cater to specific personal preferences and lifestyle choices that may influence customers to prefer certain vehicles to deliver their goods.

These issues coincide with key findings of research into city logistics for sustainable and liveable cities, which conclude that from a public utility point of view, the most important aspect is to promote a sustainable development strategy, monitoring and controlling the different types of costs generated by freight mobility in the urban area (Russo \& Comi, 2012) and that a change in mind-sets of logistics managers as well as public-private partnerships are essential for promoting sustainable city logistics (Taniguchi, 2014).

\section{Towards a typology of cycle logistics}

As the literature review and several European case studies reveal, a significant potential for cargo cycles to substitute motorised vehicles exists. However, major obstacles identified are the perception of cargo cycles as a suitable mode of transport and their acceptance by potential B2B and B2C customers. Perhaps because this is a recent field of study, there is a large variety of definitions and terms used to describe the use of cargo bikes for urban freight with little coherence in how they are used (Riehle, 2012). A similar problem has previously been identified within the field of urban freight transport as such (Lindholm, 2013).

This indicates that the language used as well as the conceptualisation of cycle logistics within existing urban logistics framework could play a significant role for the further dissemination of this innovation. This section provides definitions of common terms and a conceptual framework to support the strategic integration of cycle logistics in existing urban logistic operations and research.

According to a recent systematic literature review (Lindholm, 2013), "city logistics" seem to be the main phrase used when coming to European Commission (EC) projects or authority-initiated projects, while "urban freight" and distribution terms are used more widely in research. Due to its relevance in practice as well as in research, the term "city logistics" will be used within this paper.

The term cycle logistics includes all types of pedal cycles independent from the number of wheels as well as electrically assisted or not. Table 3-1 provides a sample of hits for different terms used to describe cycle logistic operations while Fig. 3-1 shows three different vehicle types for cycle logistics found in literature and Fig. 3-2 example pictures of cargo bikes and cargo tricyles in action.

Taking established terms and frequency into account (Armstrong, 2015; Browne, Allen, \& Leonardi, 2011; CycleLogistics consortium, 2014; Gruber, Kihm, \& Lenz, 2014; Lenz \& Riehle, 2013; Maes \& Vanelslander, 2012), the paper defines this area of research as follows: cycle logistics describes the use of human-powered or electrically-assisted standard bicycles, cargo bikes and cargo tricycles for the transport of goods between $A$ and $B$, primarily in urban areas.

Within city logistics, the following services were identified to provide a market for cycle logistics as the operations require density to harness economic advantages of this mode of transport. Last mile logistics involves items being delivered from a depot or hub a short distance to their final destination. Some larger delivery companies make the distinction between last miles (up to 10 miles/ $\mathrm{km}$ from the depot) and last metres - the actual delivery from the van in high density areas within e.g. 1 mile $^{2}$.

First mile logistics is the natural progression from last mile logistics in terms of collecting items from customers who need to send items nationally or internationally. To distinguish last mile from the more

Table 3-1

Sample of keyword searches and hits for cycle logistic term via www.sciencedirect.com in Feb 2015.

\begin{tabular}{llll}
\hline Search terms & $\begin{array}{l}\mathrm{Nr} \text { of } \\
\text { hits }\end{array}$ & Search terms & $\begin{array}{l}\mathrm{Nr} \text { of } \\
\text { hits }\end{array}$ \\
\hline $\begin{array}{l}\text { "Sustainable urban freight } \\
\text { transport" }\end{array}$ & 22 & "cargo bike" + logistics & 11 \\
"Sustainable city logistics" & 8 & $\begin{array}{l}\text { "cargo bike" + "urban } \\
\text { freight" } \\
\text { "cargo cycle" + "urban } \\
\text { freight" }\end{array}$ & 9 \\
"City logistics" & 395 & 8 \\
"Urban freight transport" & 233 & $\begin{array}{l}\text { "cargo tricycle" + "urban } \\
\text { freight" }\end{array}$ & 4 \\
bike + "urban freight" & 42 \\
"Cargo bike" & 20 & $\begin{array}{l}\text { bike + "city logistics" } \\
\text { tricycle + city logistics }\end{array}$ & 33 \\
\hline "Cargo trike" & 7 & 26
\end{tabular}




\begin{tabular}{|c|c|c|}
\hline \multicolumn{2}{|c|}{ Cycle logistics -Vehicle types } \\
\hline $\begin{array}{c}\text { 2 wheels, no cargo box } \\
\text { e-assist or not } \\
\text { also referred to as: } \\
\text { Push bike }\end{array}$ & $\begin{array}{c}\text { Cargo Bikes } \\
\text { properties: } \\
\text { 2 wheels, cargo box } \\
\text { e-assist or not } \\
\text { als referred to as: } \\
\text { Cargo bicycle } \\
\text { model example: "iBullitt" }\end{array}$ & $\begin{array}{c}\text { Pargo Tricycles } \\
\text { properties: } \\
\text { e-assist or not } \\
\text { als referred to as: } \\
\text { Small Electric vehicles (SEV) } \\
\text { Cargo trike }\end{array}$ \\
\hline
\end{tabular}

Fig. 3-1. Vehicle types of human-powered or electrically-assisted cargo cycles used for cycle logistics.

customised services, the term same day services is often used by cycle logistic operators. The cycle logistics operator receives an order to take an item from location A to location B on a particular day or even within $1 \mathrm{hr}$. This can also include picking up a parcel to be further transported by train and delivered in another city within a few hours. The delivery industry uses the term express to describe this kind of service. This paper seeks to establish the term express service also for cycle logistics.

\subsection{Cycle logistics within a sustainable city framework}

Sustainable development is characterised by economic, environmental and social sustainability. Despite various influencing factors, within urban transport it is possible to consider that economic and social sustainability can be determined by efficiency and safety, and environmental sustainability by air pollution. This is where two conflicting interests emerge - public authorities aim to reduce the transportation impacts to increase the attractiveness of their city for inhabitants and visitors (mainly environmental and social sustainability e.g. reduction of congestion, pollution, accidents), while private companies seek to operate at the lowest cost but high-quality and short time in order to satisfy the customers' expectations in a highly competitive market (mainly economic sustainability) (Russo \& Comi, 2012).

In order to identify synergies and supportive actions, the cycle logistics case studies will be discussed within the sustainable logistics framework developed by Russo and Comi (2012). This paper defines sustainable city logistics as a holistic approach to city logistics, that goes beyond zero-carbon and includes social and economic aspects such as congestion and quality of life (Fig. 3-2). Russo and Comi (2012) identify four sets of measures that can be used to understand how sustainable logistics fits into an urban area. The first set of measures relates to material infrastructure. These measures can be linear, if they refer to links of the urban transport network (e.g. use of an urban transportation); or surface (and/or nodal), if they refer to areas that can be reserved for freight operations (e.g. Urban Consolidation Centres). A second set of measures relate to the immaterial infrastructure, which includes systems for traffic information, freight capacity exchange systems, route optimisation services, other information services through internet access, and centralised route planning (Intelligent Transportation Systems). A third set of measures relate to equipment, including regulations concerning loading, handling and transport by new low-emission vehicles; on transport units, if they refer to characteristics of transport units (e.g. reduction in truck emissions and use of electric vehicles, metropolitan railways and trams). The final set of measures relates to the governance of the traffic network. In this class we can find traffic regulations (e.g. access times, heavy vehicle networks, road-pricing, maximum parking times, maximum occupied surface and specific permission). These four types of measures seek to support economic, social and environmental goals. How they apply to cycle logistics will be discussed in Chapter 5. Table 3-2 outlines the impact of different modes of transport on economic, social and environmental goals, ranging from negative (-), neutral (0) up to positive $(+)$. Business as usual utilising diesel vans has a negative impact on all sustainability goals. A modal shift to nearly zero-carbon e-mobility is strongest in addressing environmental issues while cycle logistics positively contributes to all sustainability goals.

The remainder of the paper improves our understanding of how to develop cycle logistics to reduce the adverse impacts of urban goods deliveries without reducing the quality of city living. It identifies reasons why cargo cycles have to date remained a niche solution and how they might become a viable mainstream activity in the UK, drawing implications for cities in Europe.

It seeks to tease out which factors are understood as being the most important by cycle logistics operators by conducting a comparative study across the three UK cities of Leeds, London and Cambridge. These cities were selected to represent the most common types of cities across Europe. Leeds is a northern post-industrial setting, with approximately 750,000 inhabitants and a rapidly regenerating city centre,
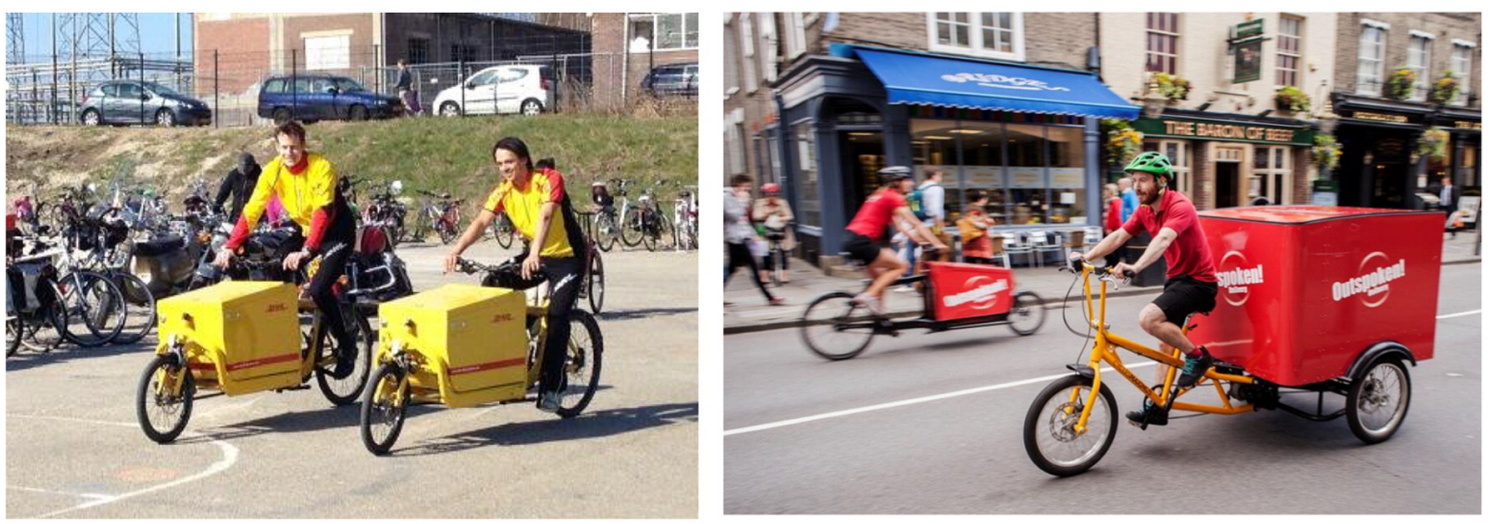

Fig. 3-2. Examples of 2-wheel cargo bikes as used by DHL and a 3-wheel tricycle as used by Outspoken Delivery. Photo credit: Mark Wagenbuur and Outspoken Delivery. 
Table 3-2

From low-carbon to sustainable city logistics. Based on Russo and Comi (2012).

\begin{tabular}{|c|c|c|c|c|c|c|c|c|c|}
\hline \multirow[b]{2}{*}{$\begin{array}{l}\text { Sustainability impact } \\
\text { Mode of transport }\end{array}$} & \multicolumn{3}{|c|}{ Economic goals } & \multicolumn{3}{|l|}{ Social goals } & \multicolumn{3}{|c|}{ Environmental goals } \\
\hline & $\begin{array}{l}\text { Traffic } \\
\text { congestion }\end{array}$ & $\begin{array}{l}\text { Delivery } \\
\text { time }\end{array}$ & $\begin{array}{l}\text { Infrastructure } \\
\text { costs }\end{array}$ & $\begin{array}{l}\text { Reduction of } \\
\text { accidents }\end{array}$ & $\begin{array}{l}\text { Reduction of } \\
\text { vehicles }\end{array}$ & Liveability & $\begin{array}{l}\text { Reduction of } \\
\text { pollutants }\end{array}$ & $\begin{array}{l}\text { Reduction of } \\
\mathrm{CO}_{2} \text { emissions }\end{array}$ & $\begin{array}{l}\text { Reduction of } \\
\text { noise }\end{array}$ \\
\hline Diesel vans (business as usual) & - & - & - & - & - & - & - & - & - \\
\hline $\begin{array}{l}\text { Modal shift to electric vans } \\
\text { (low-carbon) }\end{array}$ & 0 & 0 & 0 & 0 & 0 & + & + & + & + \\
\hline $\begin{array}{l}\text { Modal shift to cargo cyles } \\
\text { (sustainable logistics) }\end{array}$ & + & + & + & + & + & + & + & + & + \\
\hline
\end{tabular}

while Cambridge is a small city of 122,000 inhabitants with a strong knowledge economy and dense historic city centre. London is the capital city in the UK with $8.3 \mathrm{~m}$ inhabitants and a large and diverse service and retail economy. The selected companies are the leading cycle logistics operators in each city operating with distinct company models in different geographical contexts. Last Mile Leeds was established towards the end of 2012, Outspoken Delivery is the only cycle logistics operator based in Cambridge and was established in 2005, while Gnewt Cargo started in 2008.

The comparison between cities is intended to investigate the role played by different urban settings, including their governance, urban form and broader cultural and socio-economic context, in influencing the development of cycle logistics. The research took place in 2014-2015 and comprised a set of expert interviews with 4 national and international cycle logistics consultants, followed by a set of 8 case study interviews with operators in each of the three UK cities. Overall 22 interviews with cycle logistic operators and experts, bike service providers were conducted, following snowball principles to identify relevant people within the network to improve the understanding of the bike business sector in the UK. The following section presents the analysis of these interviews, which is structured around the key factors constraining and enabling cycle logistics that have been identified in the literature review. The discussion particularly focuses on how these barriers and opportunities, and the perceptions of them, both differ and are similar across cities.

\section{Cycle logistics in the UK today}

The interviews with ten cycle logistics businesses from five different UK cities (Cambridge, Edinburgh, Leeds, London and Manchester) have shown that the sector is currently dominated by small and medium sized businesses with a small number of full time and a larger number of flexible part time staffs. The rationale to start the business was in most cases driven by the motivation to contribute to a more liveable city and the sustainable ethics of passionate individuals involved. While still operating on the niche level, many small businesses seem to perceive similar businesses as direct competitors more than they would perceive businesses running on diesel vans to be their peer group. This culture reaches so far that e.g. a small cycle logistics business in Manchester refused to be interviewed in case one of their competitors was interviewed as well. Small businesses that seek to compete with larger delivery operators suffer from misperception that their business is merely a traditional bike messenger rather than a viable alternative to diesel van operation. Potential customers associate cargo cycles with

Table 4-1

Case study overview.

\begin{tabular}{|c|c|c|c|}
\hline Company & Outspoken Delivery & Gnewt Cargo & Last Mile Leeds \\
\hline City & Cambridge, UK $(122,000)$ & London, UK ( $8,3 \mathrm{~m})$ & Leeds, UK $(750,000)$ \\
\hline Since & 2005 & 2009 & 2012 \\
\hline Employees & $\begin{array}{l}3 \text { full time, a pool of } 12-14 \text { flexible ( } 7 \text { full } \\
\text { time equivalents (FTE)) }\end{array}$ & $\begin{array}{l}90 \text { fulltime, up to } 120 \text { incl. flexible members } \\
\text { of staff during high season }\end{array}$ & 2 fulltime, $2-3$ flexible \\
\hline \multirow[t]{2}{*}{ Fleet } & $7 \mathrm{x}$ cargo bikes (freight, iBullitt, truck) & 8 cargo cycles & \multirow[t]{2}{*}{3 cargo bikes } \\
\hline & $3 \times$ Cycle Maximus & 100 electric vehicles (EV) & \\
\hline Modal shift & $\begin{array}{l}\text { No info on replacement as Cambridge } \\
\text { cycling city }\end{array}$ & $\begin{array}{l}\text { Expanded from } 1 \text { EV and } 8 \text { cargo bikes to } \\
100 \text { EV \& } 8 \text { cargo bikes replacing diesel vans }\end{array}$ & Replaced 1 DHL diesel van in Leeds \\
\hline $\begin{array}{l}\text { Reason to use cargo } \\
\text { cycles }\end{array}$ & $\begin{array}{l}\text { Sustainability, company culture, accessibility } \\
\text { of city }\end{array}$ & $\begin{array}{l}\text { Accessibility and sustainability, cargo cycle } \\
\text { use reduced in London in favour of EV } \\
\text { expansion. }\end{array}$ & $\begin{array}{l}\text { Sustainability, business niche, company } \\
\text { culture }\end{array}$ \\
\hline \multirow[t]{3}{*}{ Customer } & Overall 200 customers & myHermes represents $60 \%$ of Gnewt's & \multirow{3}{*}{$\begin{array}{l}95 \% \text { of business last mile for DHL, approx. } \\
60-120 \text { parcels/day; } \\
\text { Other } 5 \% \text { : flowers, individual deliveries. }\end{array}$} \\
\hline & $85 \%$ paper, $15 \%$ other freight; mostly B2B; & turnover, TNT and DX $12 \%$ each, few & \\
\hline & $\begin{array}{l}\text { Last mile contract with TNT as suffer from } \\
\text { congestion on A14 into Cambridge. }\end{array}$ & $\begin{array}{l}\text { independent customers as management } \\
\text { costly; approx. } 4500-17,000 \text { parcels/day. }\end{array}$ & \\
\hline Competition & $\begin{array}{l}\text { No direct competition in Cambridge, seeking } \\
\text { to support and collaborate. }\end{array}$ & $\begin{array}{l}\text { No competitor in London as zero-emission } \\
\text { model unique at the moment. }\end{array}$ & $\begin{array}{l}\text { Similar businesses in same city not } \\
\text { necessarily seen as competition as enough } \\
\text { work for all }\end{array}$ \\
\hline Plans to expand? & $\begin{array}{l}\text { Via Franchising - Outspoken Glasgow set up, } \\
2-3 \text { more in pipeline }\end{array}$ & $\begin{array}{l}\text { Plans to expand business throughout UK, e.g. } \\
\text { Oxford }\end{array}$ & Plans to expand business to Manchester \\
\hline \multirow[t]{3}{*}{ Service } & Same day, & Same day, & Same day, \\
\hline & Last mile, & Express, & Express, \\
\hline & Express & Last mile & Last mile \\
\hline Infra & $\begin{array}{l}\text { Edge-of-city centre depot for last mile } \\
\text { delivery. }\end{array}$ & $\begin{array}{l}\text { Two (north and south bank) consolidation } \\
\text { centres in central London. }\end{array}$ & City centre location. \\
\hline Seasonality & \multicolumn{3}{|c|}{ Applies to all cases: 3 months before Christmas most busy times; January and 6 weeks over summer holidays least busy. } \\
\hline Additional information & $\begin{array}{l}70 \% \text { of deliveries are prescheduled; daily } \\
\text { timed collections and deliveries; } \\
\text { Collect post from Royal Mail (RM) offices to } \\
\text { ensure delivery by } 9 \text { am (which RM cannot } \\
\text { guarantee). }\end{array}$ & $\begin{array}{l}\text { Central London location ( } 25,000 \mathrm{sq} \mathrm{ft} \text { for } \\
\text { south depot) represent major fix costs, } \\
\text { Gnewt is piloting scheme to turn EV smart } \\
\text { grid into financial model which significantly } \\
\text { reduces running costs. }\end{array}$ & $\begin{array}{l}\text { Initial phase supported with UK “New } \\
\text { Enterprise Allowance scheme"; } \\
\text { Normally max } 1.5 \text {-miles delivery distances } \\
\text { from hub (Leeds } 1 \text { and } 2 \text { ) due to proximity } \\
\text { and accessibility. }\end{array}$ \\
\hline
\end{tabular}


standard bicycles and underestimate their potential to carry significant volumes or weight. This indicates that the professionalisation of the sector is to date a major challenge for its uptake as alternative to traditional motorised transport. However, a few cycle logistics businesses such as Outspokend Delivery in Cambridge and nearly zero-carbon logistic businesses like Gnewt Cargo in London have recently started to expland throughout the UK (Armstrong, 2015; Barner, 2014).

The case studies chosen to be discussed in more depth are Outspoken Delivery, Gnewt Cargo and Last Mile Leeds as operators that successfully reached a professional image and an economically viable operation. Table 4-1 provides an overview on the three snap-shot case studies with information on their urban context and business model. Outspoken Delivery represents a well-established cycle logistics operator in a small cycle-friendly city with decent cycling infrastructure. Gnewt Cargo has operated for six years and represents an interesting case, as the company evolved from a small business using mainly cargo cycles to a by now unique nearly zero-carbon logistics service provider in the City of London. Last Mile Leeds has been most recently established and serves with Leeds a medium sized city where cycling for transport is not part of the local culture.

Outspoken Delivery is the only cycle logistics operator based in Cambridge and was established in 2005. Approximately $70 \%$ of Outspoken's deliveries are pre-scheduled, including a variety of clients for whom they perform daily timed collections and deliveries. They also collect post from Royal Mail sorting offices for a variety of clients as Royal Mail cannot guarantee to deliver it by 9 am. Due to the limited accessibility of the city centre, Outspoken has gained contracts with larger delivery companies which take their items to Outspoken's edge-of-city-centre depot for Outspoken to perform the last-mile delivery. Outspoken currently have lastmile contracts with magazine publishers and several large courier companies including TNT, which often experience traffic congestion on the A14 travelling into Cambridge. Outspoken Delivery will also soon be working on a first mile basis collecting items from clients of the large courier companies and taking them back to the depot for collection. In total, Outspoken Delivery works for over 200 clients in Cambridge. Upon surveying their customers, Outspoken discovered that their largest selling points were speed and reliability. The fact that Cambridge has an established cycling culture helps overcome perception issues and cultural barriers for a modal shift towards cargo cycles.

Similar to Outspoken Delivery, Gnewt Cargo started in 2009 as a logistics business with a fleet that mainly consisted of cargo cycles - eight cargo cycles and one van - with the aim of reducing pollution, particulate emissions and congestion while performing better than its competitors. The major client at that time was stationery supplier Office Depot. Seeing the necessity to diversify and becoming more independent from this client, Gnewt decided to move away from this major customer and serve a wider range of clients, including other delivery companies as well as retailers. Today, Gnewt is a multi-award winning company that uses mainly electric vehicles and proved they are commercially viable. Having delivered approx. 1000 parcels per day in 2011, the business has grown at least $50 \%$ per year. In 2014 , the company grew $100 \%$ and doubled its electric vehicle fleet with the addition of 55 all-electric Renault Kangoo Z.E. vans and 6 Nissan ENV 200's. This followed a contract with myHermes to deliver over 6000 parcels a day which had Gnewt "take the lead on all myHermes deliveries inside the Congestion charge zone". Currently, the company delivers between 4500 - 17,000 parcels per day. myHermes represents $60 \%$ of Gnewt's turnover, TNT and DX 12\% each, and the remaining $16 \%$ consisting of a few independent businesses as the increased management costs can make small deliveries unprofitable (Clarke, 2015). Using an entirely electric vehicle fleet saves about 146 tonnes of carbon annually compared with previous delivery methods. Gnewt operates two depots in central London, which represent high fixed costs. However, due to flexible working contracts for its up to 120 staffs and smart grid battery charging for the EV fleet, the running costs remain relatively low
(Clarke, 2015). In late 2014, Gnewt's founding directors sold $49.8 \%$ of the company for a $£ 1.75 \mathrm{~m}$ cash consideration to DX. DX is a leading independent mail, parcels and logistics end to end network operator in the UK and Ireland established in 1975, which delivered approximately 170 million items in 2013 (London Stock Exchange, 2014). Gnewt now seeks to use this investment to replicate the model in other UK cities in 2015 with the stated goal of creating more jobs, bringing a quality service to clients, and helping to make city centres nicer places to be by reducing harmful emissions (Gnewt Cargo, 2015).

Last Mile Leeds was established in the end of 2012. The founder was inspired by the understanding of the inefficient and expensive current modes of last mile delivery which could be made more sustainable by using cargo bikes. The vast majority of Last Mile Leeds' work is last-mile deliveries for global courier DHL, performed on cargo bikes. Due to the city centre location of Last Mile Leeds' premises, the maximum delivery distance is approximately a mile and a half which enables them to offer DHL a very competitive price. Because of this economic advantage, DHL have replaced one of the two vans they operate in Leeds with Last Mile Leeds' services. Yet, the company owner emphasised that this was down to the "luck" of DHL agreeing to try out cycle based delivery, providing anecdotes of other failed attempts at gaining contracts with other large courier companies which were not willing to experiment with cycle logistics. Cycling for personal transport is still very niche in Leeds and likewise its use for urban freight transport. "It really has come down to one or two key people who are prepared to give it a go because they could see the potential for it" (Brocklebank, 2014). DHL treats Last Mile Leeds as a sub-contractor and pays per piece, to cater flexibly with rising or falling delivery volumes, common practice in a sector with high seasonal fluctuations. Although employing more staff might be cheaper, it would mean higher fixed costs that would decrease flexibility. DHL sends a van with 60-120 parcels per day to Last Mile Leeds' city centre unit. From here the packages are distributed within a radius of about 1-2 miles, which is "easy for [Last Mile Leeds] to do" at a competitive price of less than $£ 2$ per piece thanks to their central location. Any contract would be of similar nature and the current method has worked well for Last Mile Leeds for over 18 months (Brocklebank, 2014; Last Mile Leeds, 2014).

A major barrier to expanding cycle logistics market share is it that companies like DHL, Fed Ex, TNT and myHermes do not want parcels from different courier companies to be mixed in the same delivery vehicle. For example should Last Mile Leeds have to operate different cargo bikes for each contract, this would significantly reduce the opportunities to create economies of scale and efficient consolidation. All three case studies have one major contractor - this is in Outspoken's case that a magazine publisher followed by TNT, for Last Mile Leeds DHL and in case of Gnewt Cargo myHermes. This issue of exclusivity also means each contract requires a different form of digital proof of delivery, preventing the cycle logistics operator from using a unified system, although such unifying systems are being developed and tested by both Outspoken and Gnewt. Hence, although running on a professional basis, the business is still heavily dependent on decisions made by their major customers.

The business opportunity lies in big courier companies rather than in small and customised businesses like flower or food deliveries. The last mile is the most expensive part of the entire logistics supply chain, as one of the interviewees states "[big courier companies] are not interested in it being a van. They just have to do the deliveries as cheaply and efficiently as possible". However, although the modal shift from van to cargo cycle has begun to be accepted within DHL due to some successful partnerships, it is still "definitely niche".

\section{Cycle logistics for the sustainable city}

In the case of cycle logistics, the material infrastructure and geography and of a city are crucial if cycle logistics operations are to become economically sustainable. Narrow thoroughfares in historical city 
centres, e.g. Cambridge, favour the use of cargo cycles as they become the natural choice to enable accessibility. As Gnewt Cargo states, the vehicle choice comes down to the rationale for what is most convenient and feasible. While deliveries in London are made via electric van, when expanding their business to Oxford cargo cycles would most probably be the preferred transport mode as narrow streets only allow smaller-sized vehicles through. Further, Urban Consolidation Centres were identified to be the major complementary infrastructure to enable cycle logistics operators to keep the length of the journeys, and hence the delivery time, short.

With regards to the non-material infrastructure, it was the proof of delivery software that represents a particular barrier to efficiency, as major contractors insist that their sub-contractors use their bespoke ICT. Further inefficiencies emerge from the fact that subcontracting cycle logistics or low-carbon operators are not allowed to mix parcels from different larger delivery companies in one vehicle. This appears to be based on the scepticism and mistrust of the local depot manager as there has been no research if these concerns are reasonable. It has yet to be explored whether e.g. optimised real time tracking of freight could contribute to overcome this psychological barrier and at the same time prevent actual errors in delivery.

The equipment turned out to be another key factor for cycle logistics business to become a viable alternative to diesel vans, especially in the UK. The current electrically-assisted pedal cycles (EAPC) regulation limits the use of electric assistance to cargo cycles under $60 \mathrm{~kg}$. To date, this has been a major barrier to carrying heavier loads for UK based cargo bike businesses. However, at the end of 2014, the UK Department for Transport has announced a proposal to harmonise with EU regulations, which will most probably come into force by April 2015. In the UK context, this is a strong indicator that e-assist pedal cycles are acknowledged to be relevant for the national economy, helped by knowledge exchange with existing pilot projects elsewhere in Europe.

To develop sustainable solutions for the e-commerce fuelled increase in diesel vans within inner city centres, municipal authorities have several governance measures that will potentially support the modal shift from motorised to cycle logistics in order to achieve not only low-carbon but holistically sustainable city logistics.

Overall, material infrastructure, non-material infrastructure, equipment and governance related measures in favour of cycle logistics have the potential to support environmental, economic as well as social goals, while zero-carbon measures mainly target environmental goals. As seen in the case of Gnewt Cargo, London's zero emission zone has led to an extensive expansion of e-mobility. This successful example shows that innovative and sustainable city logistics benefit from wellexecuted local policies. However, to harness the full potential to further decrease congestion, delivery times, accidents, and infrastructure costs, greater intervention is needed where dense urban areas are not naturally restricted for vans, for instance in Leeds and Manchester.

\section{Conclusions}

This paper contributes to a new body of research that has the potential to address the current gap in knowledge and awareness required for public authorities and private companies to jointly enable sustainable city logistics. The following issues have been identified that represent the paper's major contribution and present building blocks for future research.

First, this research has identified that language represents a significant barrier for the uptake of cycle logistics as viable option for sustainable city logistics. Therefore a typology has been developed that clearly defines the vehicle and service types, which are currently not used in a coherent way and therefore add to the complexity and potentially prevent diffusion of knowledge on the subject. Based on a literature review as well as expert interviews, the paper finds that the cycle logistics has been identified to be a viable alternative to motorised vehicles and describes the use of human-powered or electrically-assisted standard bicycles, cargo bikes and cargo tricycles for the transport of goods between $A$ and $B$, primarily in urban areas. Services covered by cycle logistics are first mile, last mile, last metres and express services. Using Urban Consolidation Centre (UCC) in a city centre location as a base represents a necessary precondition to shorten final delivery distances and provide these services in an economically competitive way.

Second, current conditions and cultures, especially in the UK, prevent the professionalisation of the sector that is mainly dominated by small businesses that either do not seek to expand their operations or suffer from adverse perception by their most important potential customers. This represents a missed opportunity for cities to synergise their ambition for liveable city centres along with the growth of a new green business sector favouring local SMEs.

Third, the geography of cities plays a major role for the viability of cargo cycles as an alternative to motorised vehicles. High density urban areas, as well as narrow streets in historical city centres, naturally contribute to the attractiveness of cycle logistics. Where this is not the case, urban governance measures regarding traffic regulation orders, e.g. reducing through traffic during the day, can incentivise a modal shift.

To facilitate the shift towards holistically sustainable city logistics, local authorities need to harness the potential of cycle logistics and provide conditions that incentivise private companies such as DHL, Hermes and TNT to integrate cycle logistics into their supply chain for last mile, first mile, last metre and express deliveries through public-private partnerships. This includes measures affecting material infrastructure (transport infrastructure, e.g. dropped kerbs and cycle lanes), nonmaterial infrastructure (incentivise the integration of sustainable last mile and last metre operators in the supply chain across different companies), equipment (e-assist deregulation) as well as urban governance (such as zero-emission zones, reducing drive-through traffic, pavement parking enforcement). The efficient integration of sustainable logistics at the micro level for last/first mile and metre would not only support the decarbonisation of urban freight transport, but also represents a major opportunity to increase the overall quality of life as well as the smartness and competitiveness of a city.

To support evidence based decision making towards liveable urban areas and green local economies, future research needs to systematically investigate to how material and non-material measures, equipment and urban governance influence the modal shift towards cargo cycle use in an effective and efficient way. This includes cost-benefit analysis, pilot projects and comparative studies. Further, this paper strongly recommends qualitative and quantitative studies into how a modal shift supports economic, social and environmental goals using and expanding on the here suggested sustainable city logistics framework and terminology.

\section{Acknowledgements}

The authors would like to thank all interviewees, especially Gary Armstrong (European Cycle Logistics Federation and Business Development Manager Outspoken Delivery, Cambridge), Sam Clarke (Co-founder and CEO of Gnewt Crago) and Ian Brocklebank (Director of Last Mile Leeds, Leeds), for their vital support in this study. Being part of the Manchester Cycling Lab project, this research was supported by the Economic \& Social Research Council (ESRC) Impact Acceleration Account [grant number R116735].

\section{References}

Allen, I., Browne, M., Woodburn, A., \& Leonardi, I. (2012). The role of urban consolidation centres in sustainable freight transport. Transport Reviews, 32(4), 473-490. http://dx. doi.org/10.1080/01441647.2012.688074.

Armstrong, G. (2015, February 2). Expert interview with Gary Armstrong. European Cycle Logistics Federation \& Outspoken Delivery.

Balm, S., Browne, M., Leonardi, J., \& Quak, H. (2014). Developing an evaluation framework for innovative urban and interurban freight transport solutions. Procedia - Social and behavioral sciences, 125, 386-397. http://dx.doi.org/10.1016/j.sbspro.2014.01.1482.

Barner, E. (2014). It's boom time for Cargo Bikes. (Retrieved from http://www.ctc.org.uk/ news/it\%E2\%80\%99s-boom-time-for-cargo-bikes). 
Brocklebank, I. (2014, August). Personal communication with Ian Brocklebank. Director of Last Mile Leeds.

Browne, M., Allen, J., \& Leonardi, J. (2011). Evaluating the use of an urban consolidation centre and electric vehicles in central London. IATSS Research, 35(1), 1-6. http://dx. doi.org/10.1016/j.iatssr.2011.06.002.

Cambridge Semantics (2004). Accounting for commercial vehicles in urban transportation models.

CILT (2011). UK Freight Planning to 2035. The Chartered Institute of Logistics and Transport (Retrieved from http://ciltuk.org.uk/Portals/0/Documents/News/cilt_freight2035.pdf).

Clarke, S. (2015, January 21). Personal communication with Sam Clarke. CEO of Gnewt Cargo.

Conway, A., Fatisson, P., Eickemeyer, P., Cheng, J., \& Peters, D. (2011). Urban microconsolidation and last mile goods delivery by freight-tricycle in Manhattan: Opportunities and challenges. Presented at the Conference proceedings, Transportation Research Board 91st Annual Meeting 2012.

CycleLogistics consortium (2014). CycleLogistics Final Public Report. (Retrieved from http://cyclelogistics.eu/docs/111/D6_9_FPR_Cyclelogistics_print_single_pages_final. pdf).

De Decker, K. (2012). Cargo cyclists replace truck drivers on European city streets. Retrieved from http://www.lowtechmagazine.com/2012/09/jobs-of-the-future-cargocyclist.html

European Commission (2011). Impact assessment accompanying document to the white paper: Roadmap to a single European transport area - Towards a competitive and resource efficient transport system. Retrieved from http://ec.europa.eu/transport/ themes/strategies/doc/2011_white_paper/white_paper_2011_ia_full_en.pdf

European Commission (2014). Living well, within the limits of our planet. 7th EAP - The New General Union Environment Action Programme to 2020 (Retrieved from http://ec.europa.eu/environment/pubs/pdf/factsheets/7eap/en.pdf).

European Commission (2015). Urban mobility. Retrieved from http://ec.europa.eu/ transport/themes/urban/urban_mobility/index_en.htm

Figliozzi, M.A. (2010). The impacts of congestion on commercial vehicle tour characteristics and costs. Transportation Research Part E: Logistics and Transportation Review, 46(4), 496-506.

Cargo, Gnewt (2015). Gnewt Cargo - About Us. Retrieved February 28, 2015, from http:// gnewtcargo.co.uk/about-us/.

Grimm, N.B., Faeth, S.H., Golubiewski, N.E., Redman, C.L., Wu, J., Bai, X., et al. (2008). Global change and the ecology of cities. Science, 319(5864), 756-760. http://dx.doi.org/10. $1126 /$ science. 1150195.

Gruber, J., Ehrler, V., \& Lenz, B. (2013). Technical potential and user requirements for the implementation of electric cargo bikes in courier logistics services. German Aerospace Center (DLR), Institute of Transport Research (Retrieved from http://elib.dlr.de/82836/1/ WCTR_Gruber_Ehrler_Lenz_DLR_revised.pdf).

Gruber, J., Kihm, A., \& Lenz, B. (2014). A new vehicle for urban freight? An ex-ante evaluation of electric cargo bikes in courier services. Research in Transportation Business E' Management, 11, 53-62. http://dx.doi.org/10.1016/i.rtbm.2014.03.004.

Janjevic, M., \& Ndiaye, A.B. (2014). Development and application of a transferability framework for micro-consolidation schemes in urban freight transport. Procedia -
Social and behavioral sciences, 125, 284-296. http://dx.doi.org/10.1016/j.sbspro. 2014.01.1474

Last Mile Leeds (2014). Last Mile Leeds | Leeds cycle delivery. (Retrieved from http://www. lastmileleeds.co.uk/).

Lenz, B., \& Riehle, E. (2013). Bikes for urban freight? Transportation Research Record: Journal of the Transportation Research Board, 2379, 39-45. http://dx.doi.org/10.3141/ 2379-05.

Lindholm, M. (2013). Urban freight transport from a local authority perspective - A literature review. Retrieved from http://www.openstarts.units.it/dspace/handle/10077/ $\underline{8869}$

London Stock Exchange (2014). Acquires significant minority stake in "green" delivery services provider. Gnewt: Cargo Retrieved from http://www.londonstockexchange. com/exchange/news/market-news/market-news-detail/12177382.html.

Maes, J., \& Vanelslander, T. (2012). The use of bicycle messengers in the logistics chain concepts further revised. Procedia - Social and behavioral sciences, 39, 409-423. http://dx.doi.org/10.1016/j.sbspro.2012.03.118.

Melo, S., Baptista, P., \& Costa, Á. (2014). Comparing the use of small sized electric vehicles with diesel vans on city logistics. Procedia - Social and behavioral sciences, 111 , 350-359. http://dx.doi.org/10.1016/j.sbspro.2014.01.068.

Rawn, E. (2015). The Three-Dimensional City: How Drones Will Impact the Future Urban Landscape. (Retrieved February 2, 2015, from http://www.archdaily.com/583398 the-three-dimensional-city-how-drones-will-impact-the-future-urban-landscape/).

Reiter, K. (2013). Potential to shift goods transport from cars to bicycles in European cities (No. CycleLogistics D7.1).

Riehle, E. (2012). Das Lastenfahrrad als Transportmittel für städtischen Wirtschaftsverkehr (Master thesis) Fakultät Raumplanung: TU Dortmund (Retrieved from https://www. muenchen.ihk.de/de/standortpolitik/Anhaenge/Das-Lastenfahrrad-als-Transportmittelfuer-staedtischen-Wirtschaftsverkehr.pdf).

Rowley, Jennifer, \& Slack, Frances (2004). Conducting a literature review. Management Research News, 27(6), 31-39. http://dx.doi.org/10.1108/01409170410784185.

Russo, F., \& Comi, A. (2010). A classification of city logistics measures and connected impacts. Procedia - Social and behavioral sciences, 2(3), 6355-6365. http://dx.doi.org/10. 1016/j.sbspro.2010.04.044.

Russo, F., \& Comi, A. (2012). City characteristics and urban goods movements: A way to environmental transportation system in a sustainable city. Procedia - Social and behavioral sciences, 39, 61-73. http://dx.doi.org/10.1016/j.sbspro.2012.03.091.

Schoemaker, J., Allen, J., Huschebek, J., \& Monigl, J. (2006). Quantification of urban freight transport effects I. BESTUFS consortium.

Silva, A., \& Ribero, A. (2009). An integrated planning for cities to promote sustainable mobility. Presented at the Proceedings of European Transport Conference.

Taniguchi, E. (2014). Concepts of city logistics for sustainable and liveable cities. Procedia - Social and behavioral sciences, 151, 310-317. http://dx.doi.org/10.1016/j. sbspro.2014.10.029.

Taniguchi, E., Thompson, R.G., \& Yamada, T. (2014). Recent trends and innovations in modelling city logistics. Procedia - Social and behavioral sciences, 125, 4-14 http://dx.doi.org/10.1016/j.sbspro.2014.01.1451. 